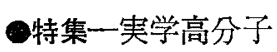

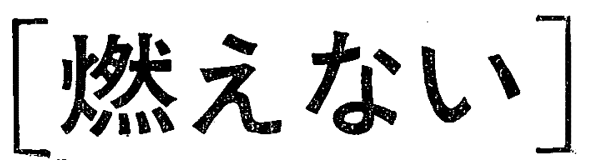

\section{綱脇 清和}

「然えない」ということを考党るには，まず「然兄 る (然焼)」とはどらいら現象か，その現象が起こるに は何が必要かを考光てみるのがわかりやすい，「然焼 之は，物質が酸素と化合する際㶴量の熱を発生し同 時飞光を発する現象」といわれている。つ方，然 光るといらことは, 化学反応が起こっているというこ とで㐫り，燃燒といら化学反応が起こるには酸素特よ び酸素と化合しうる物質が必要である。したがって 「然觉ない」とは，このいずれかが久けているといら ことであり，積極的炕こような状況炕すことが燃 辛なくすることになる。しかし，特殊な条件下以外は 酸素のない状態は考穴られないから「然兄ない」ため には物質が酸素と化合しないことが必要である。一 方，わ秃れが日常使用している高分子化合物㤝，后 とんぞが有機化合物であり，酸素と化合しうるもので あるから燃觉てあたり党のはずであるがかならずし もそらではない。どうも「然党る」現象はもら少し複 䧴なようである。

燃焼している状態を共通点を拾い出して大別すると 次の 3 種類に分類できる.

（1）気化燃燊：低分子化合物が化学変化をしない で気化し気体状態で酸素と反応 (メタノール，プロパンなど)

（2）固体燃㶹：固体状態の玉委で酸素々反応（コ 一クス, 木炭など)

（3）分解燃焼：熱分解反応飞上り低分子化合物が 生成しこれが気体状態で酸素と反 応 (一般の高分子化合物)

すなわち, 高分子化合物は「然光る」悉光法分解と Non-flammable
いうもら一つの反応が必要なので步る..したがって高 分子の場合は，熱分解しにくい，ということが燃克に くい条件の一つになる（熱分解で生成する低分子化合 物が酸素と区応しにくい場合も然えにくいのはいうま でもない).

高分子化合物の然焼を単純化して書くと次のように なる.

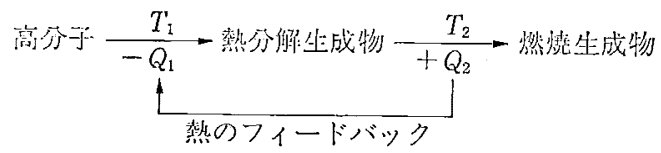

すなわち，原理的には $T_{1}$ (分解温度) おょび $T_{2}$ (発 火温度, 着火温度) が高く, $Q_{1}$ (分解吸熱) が大きく, $Q_{2}$ (燃焼発熱) が小さい汪ぞ，燃光にくくなる $\left(Q_{1}>\right.$ $Q_{2}$ であれば分解反応は継続し兄ないので自己消火す る)、原理的にはこのようにきわめて単純であるが実 際の燃烧では, 酸素の供給状態, 熱伝導性などの因子 も加わり,ささに大半の合成高分子では熱分解の前に 収縮, 溶融により形態が変化するなど高分子素材の形 状る大きく影響するため, 高分子個々の燃焼状態は最 近かなり研究が進んできてはいるが，一部を除いてほ とんどあきらかにはされていないのが実状である。い ずれにせよ有機高分子化合物で路るかぎり「然完ない (不燃)」ことはあり光ず,「然光にくい」または「然兄 にくくする(難燃化)」方法を考觉るのがより現実的と い光よう。

\section{燃えにくくする（難燃化）}

そこで然えにくくする具体的な方法について考光て みたい，これには二つの方法がある。一つは本来可然 性の素材炕然焼を抑制する作用を持つ化合物 (難燃剤) を混合, または化学的に結合させてやる方法である. もら一つは, 高分子の化学構造自体を燃觉にくいよう な形にする方法（熱分解しにくくしたり, 熱分解生成 物が不燃性であるような形にする万法）である。難然 化といわれる場合は前者を指すことが多い。これは， 現在使用されている高分子素材がそれぞれの特性によ り用途別に取捨選択されかなり特定化しているため,

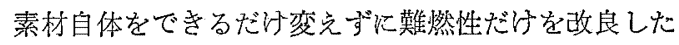
いといら考兄が強かったためと思われる（天然有機高 分子の場合はこの方法しかないが）。この方法で使用 される難然剈は多種多様であり，難燃化機構もいるい ろ説明されているが, ここでは簡単な紹介にとどめる。

1) 固相での難然化

i）物理的作用：不然性の被膜を形成して酸素との 反応を抑止したり，断熱層を形成して高分子素材 への熱エネルギー供給を抑制する.(例：ホウ砂) 
ii) 化学的作用

a) 吸熱反応 : 脱水反応, 脱ハロ ゲン化水素反応 のよらな吸熱反応により高分子素材への熱エネ ルギ一供給を抑制する（例：水和アルミナ）

b) 炭化促進: 低温で炭化分解を促進し, 燃焼温 度での可燃性ガスの発生量を減少させる.（例： セルロースに対するリン酸化合物）

\section{2）気相での難燃化}

i）物理的作用：不燃性のガスを発生し可燃性ガス を希釈, るたは酸素の拡散を抑制する.(例：アン モニウム塩, 炭酸塩)

ii) 化学的作用 : radical scavenger を発生し, $\mathrm{OH}$ ラジカルによる連鎖反応である燃焼反応自体を抑 止する.（例：ハロゲン化合物）

実際の難然化機構はこれらのいくつかが複合して作用 している. 未た高分子素材は熱的举動, 分解機構がそ

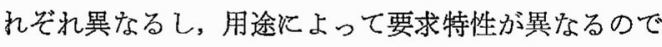
各素材, 用途に応じて難燃郕が選ばれ使用されている (例：セルロース系汇対するリン系化合物による後加 工，合成樹脂に対するハロゲン化合物のブレンド，ポ リウレタンに対する含リンジオールの共重合, アクリ ル緘維に対する塩化ビニルの共重合, ポリエステル㵶 維に対するリン系化合物のブレンド，ハロダン化合物 刀共重合，など．さらに難然剂がより效果的作用 するように助剂を併用したり(ハロゲン化合物とアン チモン化合物)，異種元素を持った化合物を使用した り(リンと窒素を持った化合物), 異なった作用機構 を持つ化合物を垪用したり（リン化合物と八ロダン化 合物）いわゆる相乗作用を利用して難然郕の使用量を できるだけ少なくする工夫がなされている、変わった 方法として，ナイロンにチオ尿素化合物を混合してや ると加熱による溶融粘度低下が大きくなる性質を利用 して，火源に接したとき溶融滴下を先行させ着火しに くくする難然化法がある。

\section{燃えにくい}

つぎにもら一つの難然化方法, 高分子の化学構造自 本を燃えにくいような形にする方法について考觉てみ 上う，熱分解江着目すると，高分子材料の燃烍性阔関 系する因子は，(1) 熱分解温度，(2) 分解熱，(3) 熱 了解速度, (4) 気体分解生成物の量, (5) 気体分解生 戈物の成分，である．これらを先に紹介した難然化の 紫構と対応させてみると, 然觉にくい高分子とは, 分 再温度が十分高いか, ある程度低くても不燃性のガ 々を放出し，主鎖の切断が起こりにくく，残渣が比軹 约強固な三次元構造になるもの，といえる。党 ボ，燃党やすさの目安である限界酸素指数（LOI :

燃㜔を継続させるのに必要な最低酸索濃度）が高分子 の構造でどのように変わるかを示すと，

$\begin{array}{lr}-\mathrm{CH}_{2} \mathrm{CH}_{2}- & \text { LOI : } 17 \\ -\mathrm{CH}_{2} \mathrm{CH}- & 45 \\ \mathrm{Cl} & \\ -\mathrm{CH}_{2} \mathrm{CH}- & 22 \\ \mathrm{OH} & \\ -\mathrm{CH}_{2} \mathrm{CH}_{2} \mathrm{O}- & 15\end{array}$

のよう変化し，二重結合が生成しやすく，分解生成 物が不然性のハロゲンを含むポリ塩化ビニルが非常に 燃光にくく, ポリビニルアルコールの異性体であるポ リエチレンオキサイドは主鎖が切断しやすいため非常 飞燃克やすくなることがかかる。, 一方, 熱分解温度が 高い高分子として耐熱性高分子がある. 実際は，耐熱 性高分子は火炎温度以下での物性の保持が重視される のに対し, 燃焼性は乞れれり高い温度での分解が重要 であるため耐熱性と難燃性は一義的には結びつかない が，熱安定性高分子は主鎖の切断が起こりにくく掉発 性の分解生成物の量も少なく, 難然性の力向にある. 事実, 耐熱性高分子は次に示与上うに然完にくいもの が多い。

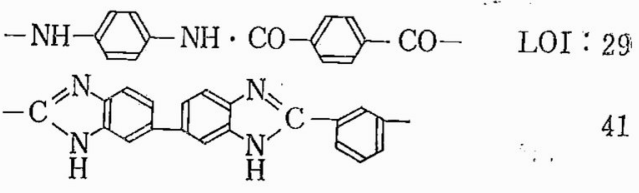

紙面の制的上過度に単純化したり, 説明不足の点む 多いが，然光にくくするとはどんなことをやっている のか, 然光にくい高分子とはどんなるのか，の一端だ けでもご理解いただければ幸いである。

\section{参 考 書}

1) 神戸博太郎編: 高分子の熱分解之耐熱性, 培風館 (1974)

2）小西 灮, 平尾正一: 難燃剂, 幸書房 (1972)

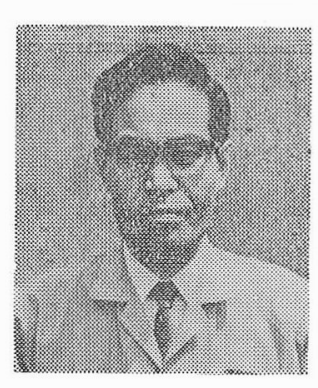

綱脇 清和

こつなわききよかず
帝人（株）松山工場テト口 工技術部 (791-41 愛媛紧松 山市北吉田町 77) 主任部員 昭和 36 年九州大学大学院 修士㹎程修了. 同年帝人入 社, 50 年末で中研勤務, 以降現職. 専門性高分子合 成. 〈趣味〉球技 (球の 大小にかかからず) 